In my recently published book Rebuilding the Kāinga, I championed the idea of kāinga in a contemporary sense: integrated housing; cultural and communal facilities; sustainable use and management of whenua, awa, and moana; and sustainable economic activities. If implemented widely, the kāinga model will also have profound impacts on how we in Aotearoa New Zealand (Māori, Pākehā, and Tauiwi-all of us) plan our homes, towns, and cities. In this intervention, I expand on, and seek to further develop, this idea in relation to current discourse regarding economics, decolonisation, and, in particular, urban planning in Aotearoa New Zealand. 


\section{Spatial Justice-Decolonising Our Cities and Settlements}

\section{JADE KAKE}

It starts with a moemoeā.

Imagine you are in your home. The morning is crisp and brilliant, but your whare is warm. From the window of your kitchen, you can see your tamariki playing together with their cousins. You walk outside the back door and into the yard. When you reach the edge of the yard, you find your cousin there. She stops briefly and tells you a story that makes you laugh, before moving on. You walk up a slight rise, and pause for a moment to look out towards the moana. You can see your uncles out on the boat fishing. For a moment, you think about your koroheke and his brothers. You hear a yell behind you and turn around to see your tamaiti running up to you, ngā hua o te rākau in her hands, with a bright smile on her face. Her nanny-your mother-trails behind.

Ko Jade Kake tōku ingoa. He uri ahau nō Ngāpuhi, Te Whakatōhea, Ngāti Whakaue. Ko au he kaihoahoa, he kaituhituhi, he kaihāpai hoki. In my recently published book, Rebuilding the Kainga, I championed the idea of kāinga in a contemporary sense: integrating housing; cultural and communal facilities; sustainable use and management of whenua, awa, and moana, and sustainable economic 
activities. ${ }^{1}$ If implemented widely, the kāinga model will also have profound impacts on how we in Aotearoa New Zealand (Māori, Pākehā, and Tauiwi-all of us) plan our homes, towns, and cities. In this intervention, I will expand on and seek to further develop this idea in relation to current discourse regarding economics, decolonisation, and, in particular, urban planning in Aotearoa New Zealand.

\section{Rebuilding the kāinga}

Käinga were the centres of hapū life pre-colonisation and during the period of early contact with European settlers. Kāinga formed the basis for our whānau structures, political organisation, and economic activities. They were deliberately sited in close proximity to significant resources and were often associated with a nearby pā. In most cases, kāinga were winter settlements, particularly for hapū who moved seasonally to mahinga kai encampments; however, some kāinga were inhabited year-round. The occupation patterns of pā varied: some were fortified village bases, others were defensible boltholes in times of conflict or uninhabited storehouses. Both kāinga and pā consisted of dense clusters of dwellings arranged in whānau groups, with communal facilities sited in accordance with tapu and noa. ${ }^{2}$

Kāinga largely operated on a subsistence basis, with internal production and distribution of goods and services to meet the needs of the community. The production of specialised goods and services was oriented to customary exchange-also known as the koha economy_which was essential for maintaining positive relationships between hapū and securing both political stability and access to resources. The arrival of Europeans introduced new technologies and pragmatic exchange flourished in the early contact period, with Māori enthusiastic and effective adopters of international trade.

The signing of te Tiriti o Waitangi in 1840 , and the breaches that

1 Jade Kake, Rebuilding the Käinga: Lessons from Te Ao Hurihuri (Wellington: BWB, 2019).

2 The discussion here draws on my research for Rebuilding the Käinga. 
followed, led to the erosion of Māori lands and their resource base. It was this, rather than the introduction of new technology and trade, that led to the most significant changes in Māori economic and political structures. The control of land, and the establishment and dominance of settler political and economic systems that favoured the rights of the individual over the communal, led to an effective dismantling of the Māori economy, and saw Māori participation in the settler-capitalist economy increase over time as a matter of necessity.

This shift has been described by Coleman et al as, 'the transformation of Māori from members of a tribal based, communal culture at the beginning of the nineteenth century to members of an individualistic capitalistic culture at the end of the twentieth century'. ${ }^{3}$ This is at least partially true; however, it fails to capture the various ways in which Māori social and political structures, and accompanying culturally based practices of reciprocity, have, to varying degrees, been maintained parallel to, and outside of, the capitalist economy from 1840 through to the present day.

Although iwi had no real political or economic function (including authority over land and natural resources) pre-colonisation, the Crown has shown a strong preference for working with iwi or 'large natural groupings' of hapū in Treaty of Waitangi settlement processes. Post-settlement iwi asset holders have, at times, been criticised for their focus on growing and maintaining economic wealth through participation in capitalist markets. Dominic O'Sullivan identifies an inherent paradox: through market participation, 'Māori economic entities position themselves to pursue collective interests and thus challenge the constraints of the neoliberal order while simultaneously pursuing its possibilities' ${ }^{4}$

In Rebuilding the Käinga, I put forward a model for thinking about how the koha economy could be reinstated in a contemporary sense. In

3 Andrew Coleman, Sylvia Dixon, and Dave Maré, 'Māori Economic Development - Glimpses from Statistical Sources,' Wellington, Motu Economic and Public Policy Research, 2005, 14.

4 Dominic O'Sullivan, 'Māori, the State and Self-determination in the Neoliberal Age,' in The Neoliberal State, Recognition and Indigenous Rights: New Paternalism to New Imaginings, eds. Deirdre Howard-Wagner et al (Canberra: ANU Press, 2018), 242, 244. 
Aotearoa New Zealand, the transfer of land, resources, and power back to Māori has yet to occur to any meaningful degree. These are all required for genuine decolonisation to occur, and are, not coincidentally, likely pre-conditions for the development of viable alternative economies. In the development of this model, I attempted to reconceptualise the Māori economy based on the kāinga as the primary economic unit, with two kinds of exchanges internally: customary/koha, which are reciprocal exchanges regulated by tikanga; and commercial exchange (barter or cash) operating as a closed market (where buyers and purchasers are restricted, for example, to neighbouring kāinga or hapū). In a contemporary sense, I believe reframing how the Māori economy is understood necessarily requires embracing complexity and seeking to reinstate our social, political, and economic structures (and the cultural values that underpin them) wherever possible, while maintaining participation in the wider economy and pursuing trade relationships.

Rebuilding the Käinga concluded with the admission that the application of this model will no doubt positively influence the lives of those whānau and hapū who have retained control of whenua Māori, and may also have some impact on local economies, particularly in rural and regional areas. However, unless significant lands (currently, only 5.5 percent of the New Zealand land base has been retained under Māori freehold title) and waters are returned to Māori communal stewardship, then this theoretical idea of a contemporary koha-based economy is unlikely to be realised to the extent that it might be truly transformative.

\section{Practical decolonisation}

The New Zealand settler colony continues to exist on unceded territory. This is something that Māori, and, in particular, Ngāpuhi, have long asserted. In 2014, a landmark Waitangi Tribunal finding demonstrated unequivocally that Ngāpuhi did not cede sovereignty with the signing of te Tiriti o Waitangi in 1840 , a finding which was strengthened by the unequivocal assertions of sovereignty made through He Whakaputanga 
five years earlier. ${ }^{5}$ The implications of this finding are yet to be seriously addressed by the Crown. However, the work of Margaret Mutu, Moana Jackson, and others through Matike Mai has provided a practical framework for considering the question of constitutional transformation. ${ }^{6}$

In the 1950s, the United Nations initiated a global decolonisation movement, in which colonising nations were required to surrender their colonies, which were then supported on a pathway towards selfdetermination and self-government. ${ }^{7}$ Settler colonies such as New Zealand, Australia, Canada, and the United States were exempt from the global decolonisation process due to the Blue Water or Salt Water thesis, which asserted that colonial nations and their colonies must be separated by 'blue water' (or some other form of substantial geographic separation) to be eligible for decolonisation. Where the colonisers had formed permanent settler colonies with functioning governments, they were not required to relinquish sovereignty, regardless of the means through which this had been attained.

'Decolonisation' is a concrete and yet oft-misused term, with the 'softening' of definition through inaccurate usage itself one of the many ways settler colonialism justifies and legitimises its continued existence. In the colonial United States, Eve Tuck and K. Wayne Yang present a useful critique of the use and misuse of the term 'decolonisation', asserting that 'Decolonization is not a metaphor' ${ }^{8}$ At a minimum, decolonisation requires the return of land and resources and the transfer of power. In Aotearoa New Zealand, this has been facilitated, to a limited degree, through the Treaty

5 Waitangi Tribunal, 'He Whakaputanga me Te Tiriti - The Declaration and the Treaty: The Report on Stage 1 of the Te Paparahi o Te Raki Inquiry,' Lower Hutt, Legislation Direct, 2014.

6 Matike Mai, 'He Whakaaro Here Whakaumu Mō Aotearoa: The Report of Matike Mai Aotearoa - The Independent Working Group on Constitutional Transformation,' Auckland, Matike Mai, 2016.

7 UN General Assembly, 'The Right of Peoples and Nations to Self-determination,' Geneva, United Nations, 1952.

8 Eve Tuck and K. Wayne Yang, 'Decolonization is not a metaphor,' Decolonization: Indigeneity, Education \& Society 1, no. 1 (2012): 1-40. 
of Waitangi settlement process, which typically involves the return of, or compensation for, 1 to 3 percent of the estimated loss in the form of land and cash resources. Some Treaty settlements also provide for co-governance over, or co-management of, significant sites and natural resources, which provide some transfer of power, again, to a limited degree.

Internationally, the land back movement has gained some traction in Canada and Australia, including through the actions of private landowners who have proactively sought to return land to tribal ownership. ${ }^{9}$ In 2019, The Yellowhead Institute published Land Back: A Yellowhead Institute Red Paper, an Indigenous-authored policy document which examines the current situation of land dispossession in Canada (particularly as it relates to resource extraction), and considers the mechanisms available to Indigenous peoples for participation in resource management and the practical mechanisms available to enable the transfer of powers and land reclamation. ${ }^{10}$ In Aotearoa New Zealand, practical decolonisation, underpinned by te Tiriti o Waitangi, could be used not only to redress past wrongs but to build a more just, equitable, and inclusive society.

\section{Spatial justice}

In Rebuilding the Käinga, I emphasised the political and economic aspects of this idea, with limited consideration of how it might intersect with urban planning, urban design, and corresponding notions of spatial justice. I have since given increasing thought as to how the theories and methods underpinning my professional discipline as an architect might relate to the kāinga concept, principally as a means for realising spatial justice in our cities in Aotearoa New Zealand.

9 Phoebe Hosier, 'More private landowners looking at giving their properties back to Tasmanian traditional owners,' $A B C$ News, 3 November 2019; 'One woman's plan to give back: "The land needs to be returned to Indigenous peoples,"' $C B C$ Radio, 20 October 2017.

10 Yellowhead Institute, 'Land Back: A Yellowhead Institute Red Paper,' Toronto, Yellowhead Institute, 2019. 
In the previous section, I outlined the conditions for decolonisation, which, at a minimum, requires the return of land and resources and the transfer of power. Indigenisation is a complementary concept that can be used to describe the 'softer' interventions or moves towards decolonisation. Within the built environment, Indigenisation may include increased participation of mana whenua in design and development projects, the visible transformation of cities to reference Indigenous history and culture, and increased Māori participation in built-environment professions as students and practitioners. It may also involve efforts to Indigenise professional bodies and the curricula of professional qualifications in planning, architecture, landscape architecture, and urban design.

\section{Housing and land-use legislation and policies}

The establishment of the New Zealand Constitution Act by the Parliament of the United Kingdom in 1852 allowed for the right of settlers to form government and to make laws. The provisions in te Tiriti o Waitangi, as intended, were to allow the Crown to establish laws to govern British citizens; however, these were subsequently applied to Māori. The Pākehā ture that have since been enacted have frequently been used to legitimise the colonisation of Aotearoa and further the goals of the colonial project. This initially involved the dispossession of Māori from our whenua and our kāinga; it later entailed discouraging or actively preventing any possibilities of rebuilding, reconnection, and return. ${ }^{11}$

The Torrens title system, which was introduced in 1870 through the Land Transfer Act (now 2017), laid the foundation for our current system

11 The use of Pākehā ture to dispossess Māori has been well documented through Waitangi Tribunal inquiries into historic breaches of te Tiriti o Waitangi. Research reports include Bruce Stirling and Richard Towers, 'Not With the Sword But With the Pen: The Taking of the Northland Old Land Claims. Part 1: Historical Overview,' Waitangi Tribunal Research Report, WAI 1040, A009, Wellington, 2007; Bruce Stirling, 'Eating Away at the Land, Eating Away at the People: Local Government, Rates, and Mãori in Northland,' CFRT no. A15, Wellington, 2008; Cathy Marr, 'Public Works Takings of Maori Land, 1840-1981,' Waitangi Tribunal Rangahaua Whanui series, Wellington, 1997; Tom Bennion, 'Māori and Rating Law,' Waitangi Tribunal Rangahaua Whanui series, Wellington, 1997. 
of individualised private-land ownership. Private-property ownership was also linked to political rights, as initially the right to te pōti was only extended to individuals who owned private property, which excluded Māori, who owned land communally. The conversion of the vast majority of customary land to the native-title system signalled the beginning of the individualisation of Māori land, in particular, through the ten-owner rule and the fragmentation of land into increasingly smaller shareholdings with each generation of succession. This meant that land was more susceptible to being sold by individual Māori to settlers, which occurred alongside outright theft, illegitimate sales, and economic coercion through the imposition of rates and land-registration fees.

Although a banking system was introduced to New Zealand in 1847 , credit was generally not made available to Māori, and finance for land and housing development was restricted to borrowing against titles held by individuals, which could be more readily seized in the event of a default. Alongside these restrictive lending practices were the various laws and ordinances (as described above) that were introduced to prevent traditional, affordable construction methods and patterns of settlement. In 1929, Minister of Native Affairs Sir Apirana Ngata secured government financial support for the development of Māori land, which was implemented through the Māori-land-development and native-affairs-housing schemes. To this day, government policies and banking practices continue to discriminate against Māori and disincentivise communal ownership of land. Serious reform-of legislation such as the Local Government Act, Te Ture Whenua Māori Act, and Resource Management Act 1991, as well as banking/finance-sector practices and their regulation-is required to enable the effective collective development, use, and re-occupation of whenua Māori by landowners. ${ }^{12}$

Urban planning in Aotearoa New Zealand has fundamentally colonial and racist beginnings. Many of New Zealand's settlements were established on raupatu land; sometimes land was gifted in good faith for this purpose, although often the terms of the original agreement were not honoured.

12 See Kake, Rebuilding the Käinga, for a full discussion of the reforms needed. 
Colonial street grids, some of which were literally drafted in England, were applied without consideration of topography or the natural features of the land. The New Zealand system of planning is based on that of the United Kingdom, which in turn originated with the industrial revolution and associated problems of safety and sanitation in European cities. In New Zealand, urban planning was established as a legislated practice through the Town and Country Planning Acts 1953 and 1977.

Other pieces of early legislation specifically sought to ban or restrict Indigenous construction methods, such as the Raupo Houses Ordinance, passed by the Legislative Council on 3 March 1842 and followed by various other city-specific ordinances. Ben Shrader provides a good overview of Māori participation in cities: he details the various ways in which Māori were excluded from the development of urban areas, but also how they exerted agency and influence on such developments. ${ }^{13}$ Land theft, ruralto-urban migration, and racist and assimilationist housing legislation and policies post-World War II effectively dismantled Māori settlement patterns and hapū-based economies. Such processes are not unique to colonialism in New Zealand; as Sápmi scholar Rauna Kuokkanen notes, 'there is a long history of various government policies and regulations limiting the possibilities of practicing traditional economic forms and removing Indigenous people from land'. ${ }^{14}$

Over time, the recognition of te Tiriti o Waitangi has been strengthened through various pieces of domestic legislation. As an agreement, te Tiriti is only enacted so far as it is recognised within New Zealand legislation, notably the Resource Management Act 1991 (RMA), which replaced the Town and Country Planning Act and other key pieces of legislation as part of a comprehensive reform of Aotearoa New Zealand's resource-management system. In particular, the RMA provides various opportunities for the transfer of powers to occur, specifically to iwi authorities, but this has been

13 Ben Schrader, The Big Smoke: New Zealand Cities 1840-1920 (Wellington: BWB, 2016).

14 Rauna Kuokkanen, 'Indigenous Economies, Theories of Subsistence, and Women: Exploring the Social Economy Model for Indigenous Governance,' The American Indian Quarterly 35, no. 2 (2011): 223. 
later extended to hapū through legal interpretations and precedents. ${ }^{15}$ The other key piece of legislation governing planning in Aotearoa New Zealand is the Local Government Act 2002, which establishes a framework for local and regional government, and requires local government to produce district plans which establish zones and rules for land use. As we continue forward into the post-Treaty-settlement era, coupled with the increasing liberalisation and diversification of Aotearoa New Zealand society, we are presented with a significant opportunity to rethink our legal mechanisms for, and practices of, urban planning and renewal to align with te Tiriti o Waitangi.

\section{The role of housing and settlements in urban transformation}

New urbanism emerged in response to suburbanisation in Western settlercolonial nations, and set out 10 principles for better urban planning. The ideas of new urbanism-which have to a large degree informed urbandesign policy and practice in Aotearoa New Zealand-are compelling, but for the most part fail to meaningfully incorporate Indigenous perspectives and precedents for settlement patterns and urbanisation.

In Aotearoa New Zealand, the kāinga model has the potential to impact on settlement patterns in two ways: through the re-establishment of kāinga on whenua Māori, approximately 5 percent of land; and through the application of kāinga organisation and management principles to urban regeneration projects in urban areas, which must be led by mana whenua.

Mosaic land-use planning, planning for a diversity of uses through comprehensive land-use plans, is now well supported by Te Puni Kōkiri, the principle funder for development on whenua Māori. This approach is further supported by progressive papakāinga district-plan provisions in areas such as Whangārei, Heretaunga, and the Western Bay of Plenty, which enable the lodgement of papakāinga development plans (masterplan and associated technical reports) at a land block or precinct level as a permitted

15 For example: Barker \& Associates, 'Section 32 Evaluation Report Plan Change 94B - Phase Two Papakāinga Provisions, Appendix F - Thomson Wilson Legal Opinion re Transfer of Powers,' http://www.wdc.govt.nz/PlansPoliciesandBylaws/ Plans/DistrictPlan/DistrictPlanChanges/Documents/PC-94B-Papakainga/1-GeneralInformation/Appendix-F-Legal-Opinion-re-Transfer-of-Powers-Provisions.pdf 
or restricted discretionary (non-notified) activity.

Urban-development legislation - which will apply nationwide but is of particular relevance to highly urbanised areas - is currently being considered by select committee. Public submissions have closed, and the final report by the Environment Committee is due to be completed June 2020. The bill introduces a range of enabling powers to fast-track urban-development and urban-renewal projects. Once passed into law, urban-regeneration projects will be implemented by Crown entity Käinga Ora, established through a previous piece of legislation. Kāinga Ora will have a significant role, and unprecedented powers, in master-planning and reshaping urban-settlement patterns in Aotearoa New Zealand cities, and the Urban Development Bill, which will establish its powers, has reasonably strong provisions for iwi/ hapū governance and participation.

The application of kaupapa-Māori urban-design principles (which I would consider an example of Indigenisation) driven and governed by mana whenua, is important if these regeneration projects are to genuinely reflect a localised sense of place and our national commitment to te Tiriti o Waitangi. These principles include: recognition of culturally significant landmarks, natural features, ecology, plant species, and narratives; integrated neighbourhood development that incorporates economic activities, environmental stewardship, and community amenities; housing configurations that are fit for Māori whānau formations and cultural practices, and sensitive to those of Pasifika and other ethnic groups; and a diversity of affordable and secure tenure options outside of individual or private-property ownership are all potential ways in which the principles of papakāinga could be applied to urban regeneration projects. For these design principles and practices to have integrity, however, definition and control must be held by mana whenua, and this necessarily requires ceding and sharing power.

\section{Collective governance as driver of urban change}

The Waitangi Tribunal claims process has produced a detailed and reasonably accurate picture of how hapū have lost land that had previously been held 
in common. The return of land and assets through Treaty of Waitangi settlement processes, however, has seldom been well-aligned to the specific hapū or kāinga who experienced that loss, owing in part to the system of calculating 'quantum' for commercial redress based on the number of tribal members/population, and because the entities for receiving and managing redress are generally established at an iwi level.

There is an argument to be made for realigning our Māori economies and governance entities to the kāinga unit. Kuokkanen provides three practical steps for such a realignment: take into account the continued significance of Indigenous economies when considering the structure or entity for Indigenous governance; use Indigenous social and economic organising systems as the blueprint for establishing political institutions; and restructure the legal and justice system around customary laws and behaviours embedded in Indigenous economic systems and affiliated social institutions. ${ }^{16}$

On whenua Māori in particular, and potentially Treaty-settlement land, the establishment of kāinga-based systems of collective governance (in parallel to the wider continued movement towards Indigenous selfdetermination and tino rangatiratanga) could begin to shape not only land-use-planning practices, but also the laws that govern these activities, economic systems, and systems of political representation.

In the urban-regeneration example, split-tenure models, whereby the house and underlaying land are held under separate titles, as well as communal-ownership models such as cooperatives, all provide opportunities for collective governance, with a potential power-sharing arrangement between mana whenua (who may own/retain control of the land) and home occupiers (the majority of whom would be unlikely to be mana whenua, but who may hold the legal right of occupation and part-responsibility for the collective management and maintenance of communal spaces held in common). Hyper-localisation, with decision-making powers devolved to a local level and aligned to Indigenous social and economic systems, provides opportunities for genuine decolonisation beyond Indigenisation. 


\section{Conclusion}

Urban planning is not only a spatial consideration but also a political and economic one. In this intervention, I have attempted to sketch the ways in which practical decolonisation could apply to how we plan our settlements in Aotearoa New Zealand. Central here is the Māori concept of kāinga as a settlement-planning model, social-organising principle, and political and economic unit. Considered holistically, the implementation of a kāingabased model has the potential to significantly disrupt existing-and feed into new-systems of urban planning, finance, economics, and politics. 